\title{
Matthew Eisler
}

Much of the extant literature assessing the Austrian Socialist Party's (SDAP) social welfare programs in post-First World War Vienna tends to interpret these as the product of a paternalistic and conservative 'Germanophile' party. Many scholars claim the Socialists suppressed spontaneous working-class political activism, dulling the consciousness of soldiers and workers to the imminent danger to the Republic posed by Austrian fascists. This essay instead proposes that there was a more complex relationship between the SDAP elite and its rank and file than has previously been thought. In attempting to engineer a new socialist society, the party combined progressive and traditional aspects in its welfare programs in an effort to both control and strengthen proletarian political consciousness. The ambiguous results of this program belie claims that the Viennese working class was supine either in the face of the SDAP's 'cultural offensive' or the right-wing reaction.

One of the main criticisms of the Austrian Socialist Party (SDAP) between 1918 and 1934 has been that its leadership was undemocratic, patriarchal, and traditional. Certain leftist scholars in particular have linked the collapse of the First Republic and the triumph of the reactionary right to the estrangement of the party from the working class, the chasm between the values of the mandarins of the socialist intellectual elite and proletarian culture. While much was accomplished in the social realm in Vienna by the SDAP, the critics acknowledge, there was much left to be desired. The Socialists did not take workingclass experience and needs into account when developing their urban institutions and programs, ignored 'popular' and 'mass' culture, and overwhelmed Viennese workers beneath a deluge of party initiatives that placed far too much emphasis on classical German philosophy and art. Consequently, proletarian political consciousness and revolutionary vitality was enervated.

Many scholars have commented on what they see as the specious nature of the SDAP reforms. Jill Lewis, for example, cites Käthe Leichter's 1931 survey of Viennese working women and their impressions of the social welfare programs. Among other things, the study revealed that the daycare system, one of the Socialists' 'crown jewels,' was not widely used by working women because it opened at 
8:00 a.m., one hour after the factory shift had already begun. Further, married women had little time to participate in the extensive network of clubs and societies organized by the party. ${ }^{\prime}$ Helmut Gruber observes that much party cultural literature was simply ignored by workers. ${ }^{2}$ More serious is his suggestion that the 'force-feeding' of socialist dogma to the proletariat sapped its revolutionary spirit and brought about the ossification of socialism as a popular political movement, unable to mobilize against the gathering forces of the right. Geoff Eley employs a similar line of reasoning, implying that the SDAP's estrangement from popular working class culture created a socio-cultural vacuum filled by the fascists. ${ }^{3}$ This was also the view of figures in the left opposition to the SDAP at the time such as Ilona Duczynska. ${ }^{4}$

There is little dispute among historians that the party leadership had by 1927 abrogated responsibility following the events of 15 July of that year, when dozens of demonstrators protesting the acquittal of extremists accused of murdering two socialists were shot down by the Viennese municipal police. The question is whether the failure of the Socialists to intervene in the riot and successfully stage a general strike in response was evidence simply of listless leadership in a party that distrusted its own workers and soldiers, or proof that the SDAP's socio-cultural program had fatally damaged proletarian political activism.

Historians generally agree that the party's intellectual elite, an "oligarchy," as Mark E. Blum puts it, jealously hoarded power within the executive, viewing with suspicion the radical local worker-soldier councils that developed following the collapse of the Dual Monarchy in November 1918 and gradually co-opting them until they were more or less completely dominated by the Socialists. However, in assessing the ways in which the SDAP's socio-cultural policy reshaped public and private space in Vienna and attempted to imbue the proletariat with socialist consciousness, it emerges that there are a number of factors

${ }^{1}$ Jill Lewis, Fascism and the Working Class in Austria, 1918-1934 (Providence, RI: Berg Publishers Ltd., 1991), 85.

${ }^{2}$ Helmut Gruber, Red Vienna: Experiment in Working-Class Culture, 19191934 (New York: Oxford University Press, 1991), 90-1.

${ }^{3}$ Geoff Eley, "Cultural Socialism, the Public Sphere, and the Mass Form:

Popular Culture and the Democratic Project, 1900 to 1934," in Between Reform and Revolution: German Socialism and Communism from 1840 to 1990, eds. David E. Barclay and Eric D. Weitz (New York: Berghahn Books, 1998), 335. ${ }^{4}$ Ilona Duczynska, Workers in Arms: The Austrian Schutzbund and the Civil War of 1934 (New York: Monthly Review Press, 1978), 27-31.

${ }^{5}$ Mark E. Blum, The Austro-Marxists, 1890-1918: A Psychobiographical Study (Lexington: University Press of Kentucky, 1985), 13. 
suggesting that party leaders had a more complex view of democracy and civic responsibility than indicated in the scholarly record. While they saw the expansion of socialism to the federal state level being accomplished through parliamentary democracy, there is no doubt they also attempted to monopolize power on the left. As such, the SDAP had an ambivalent understanding of democracy, viewing it both as the ultimate means by which the party would win power and as a potential threat in the hands of 'irresponsible' rank-and-file members. As a result, the Socialists saw mass electoral participation at the municipal, provincial, and federal levels as essential to achieving their goals, but also did their best to exculpate 'grass-roots' democratic initiative from the party's institutional structure.

The Socialists appear to have understood intra-party democracy as desirable once competing popular institutions had been dismantled, 'deviations' corrected, and the proletariat successfully steeped in AustroMarxist theory via a reformed educational curriculum, ensuring the 'responsible' wielding of popular power. While the party suppressed the post-war worker-soldier soviets and strained to exert control over the application of its own social-cultural initiatives, it also attempted to 'democratize' elite culture, to foster in the proletariat an appreciation for classic bourgeois plastic arts, music, and literature. More importantly, the SDAP's secondary educational program simultaneously inculcated in students a respect for and criticism of authority. This seemingly contradictory policy eventually fostered an activist movement that would later form the core of the left opposition that emerged to challenge the intellectual elite's grip on the party after 1927.

The tension in the party's understanding of democracy may be traced to the way Austro-Marxist theory, the guiding philosophy of Austrian social democracy, developed and informed party policy in hostile political and economic conditions, pressures that gradually increased in the post-war era. Out of the morass of war, revolution, and counterrevolution came the imperatives that shaped the institutional structure, and thus the public-private matrix, of Red Vienna. Often conceptualized by historians as a 'fortress' behind which the Socialists retreated as the federal political machinery increasingly came under control of the Christian Socials and their right-wing allies, Vienna might alternately be conceived of as a 'cultural cocoon,' enveloped by the institutional fibres of social welfare and pedagogy. Aware of the strategic and economic weaknesses of the rump Austrian Republic and guided by the AustroMarxist philosophy of incremental revolution through long-term socio- 
cultural change, ${ }^{6}$ the SDAP promoted moderate democracy in the broad political, and to a lesser degree, cultural realms. Yet the party also restricted dissenting politics within the nascent institutional apparatus that reproduced these social democratic values for fear of provoking a right-wing reaction imperiling the very structure 'incubating' the gradualist social revolution. This new socialist urban society did not emerge stillbom, as critics have claimed. Rather, it made important developmental gains, but emerged too slowly in the rapidly changing socio-political environment to effectively counter the concurrent defeatism of the party leadership and the growing right-wing threat.

The contrasting views of James Donald and Jürgen Habermas on the democratic responsibilities of citizens, as outlined in Donald's Imagining the Modern City, serve as a valuable comparative device that may help illustrate the unique episode of 'civic identity construction' that took place in Vienna during this period. Donald notes that Habermas, in a 1992 article in New German Critique, understood the urban dweller as having political responsibilities as a "constitutional patriot," a "statecitizen" interested in debate and ends, but also burdened with obligations, creating and discarding laws and reaping the rewards of activism. ${ }^{7}$ This conception of civic identity has all ethnicity bleached out of it. Donald observes that Habermas's vision is related to the French idea of nation as a civic-political entity, an institutional and territorial space much more secular than the German understanding of citizenship based on membership in an ethno-racial community. ${ }^{8}$ In the French model, nationhood and citizenship are not fixed categories, but are contested daily in the obligatory "noisy, fractious, and routine" participatory negotiation of identity. They are not the patrimony of an ancient society, but rather the synthetic products of the pressures of modernity as Marshall Berman defines them, the constructive and destructive social forces unleashed by the rapid expansion of science and technology in the service of global capitalism. ${ }^{10}$

In contrast, Donald understands democracy as a passive process, a bridge between "abstract subjects." He sees citizens as "empty space"

\footnotetext{
${ }^{6}$ Anson Rabinbach, The Crisis of Austrian Socialism: From Red Vienna to Civil War, 1927-1934 (Chicago: University of Chicago Press, 1983), 123.

7 James Donald, Imagining the Modem City (Minneapolis: University of Minneapolis Press, 1999), 97-102.

${ }^{8} \mathrm{Ibid} ., 98$.

${ }^{9}$ Ibid., 98.

${ }^{10}$ Marshall Berman, All That is Solid Melts Into Air: The Experience of Modernity (New York: Simon and Schuster, 1982), 16.
} 
subject to a symbolic order, with no identity except that produced by the "Law." The latter thus defines individual personae, rather than citizens defining themselves in the laws they popularly create. ${ }^{11}$

The social engineers planning Red Vienna in the early 1920 s perceived democracy and civic identity in a way somewhere between the active and passive concepts of citizenship as Habermas and Donald respectively understand them. This hybrid view combined the obligation of the SDAP elite to use the new socialist institutions both to transmit the classical German cultural heritage to the predominantly ethnically German proletariat, as well as instill in workers a sense of critical thinking and questioning of authority. As such, the party leadership cannot be understood strictly as a chauvinist clique that conceived citizenship and nationhood in purely ethno-cultural as opposed to political terms, as critics such as Geoff Eley, Mark Blum, and Helmut Gruber have claimed. Instead, the Socialists blended traditional and progressive values in building Viennese institutions and their vision of citizenship.

There is little question that SDAP leaders, following the party's birth in 1889 , understood as one of their key roles the teaching of the responsibilities and expectations of social democracy to workers. This didactic function was reflected in intra-party procedural protocols, where there was a divide between the elite and the rank and file and an absence of democracy in shaping the Executive Committee. Only about half of the 300 delegates were typically elected to attend leadership conventions, the rest being appointed. ${ }^{12}$

However, the image of an inflexible, insular, and paternal party that alternately scomed and/or feared its constituency does not do justice to the complex socio-economic and political context within which the Socialists operated. One important consequence of this was that SDAP cosmology was constantly in flux as the party responded to the fluid environment of the pre-war Dual Monarchy and the post-war Austrian Republic. Prior to the First World War, Habsburg political repression and ethnic discord led the SDAP to favour change through gradual parliamentary reform and the development of the bildungsgemeinschaft, the enlightened community. ${ }^{13}$ With political options thus circumscribed, the party believed that the classical anti-individualist German cultural and philosophical heritage, made available to the multi-ethnic proletariat, was the essential bonding agent that could overcome the national

"Donald, Imagining the Modern City, 100-1.

${ }^{12}$ Blum, The Austro-Marxists, 13.

${ }^{13}$ Rabinbach, The Crisis of Austrian Socialism, 16. 
chauvinisms of the constituent peoples of the Empire. ${ }^{14}$ In turn, this would facilitate the socialization of the economy and democratization of the workplace. However, the universal and parochial aspects of this program could not be reconciled. The gradual erosion of inter-party solidarity as a result of increased nationalism, combined with the advent of the First World War and the devolution of Austria-Hungary into its constituent states, ended all hope that a successor socialist federal state embracing the various ethnic groups could replace the Empire.

Massive socio-economic upheaval thus determined SDAP policy as it reacted to rapidly changing events on the ground. In this environment, party leader Otto Bauer believed the only path left for tiny Austria was union with Germany, a hope dashed by the Allied recognition of the former in the Treaty of St. Germain. As a result of its commitment to attain power strictly through parliamentary means, the party was able to participate in federal politics in the First Republic only briefly, forming a coalition government with the Christian Social Party and the National Association Party until 1920, when the right wing of the alliance won 108 of 174 seats. $^{15}$ With the SDAP relegated to the opposition and the capitalist structure intact, the Socialists were forced to abandon the two most important aspects of their pre-war program, the socialization of the economy and the democratization of the workplace. ${ }^{16}$ As Jill Lewis notes, Vienna, a Socialist stronghold, became the only possible venue in which the party could execute its political agenda. ${ }^{17}$ With the avenues of action thus limited, welfare reform, political pedagogy, and municipal socialism formed by default the main thrust of the SDAP's practical program.

As a doctrine shaped by contingency in this unique and unstable milieu, Austro-Marxism was reactive and of limited utility as a guide to action. It was further hampered by its inherent positivist-evolutionist tendencies, the idea that the inexorable movement of historical economic forces would irrevocably result in socialism. ${ }^{18}$ Though the Socialists always saw parliamentary elections as the ultimate vector of the revolution, they also conceived of 'power' as devolving from institutions that would be 'inherited' as a result of this inevitable historical movement, not taken in struggle. Consequently, SDAP leaders de-

\footnotetext{
${ }^{14}$ Ibid., 16.

${ }^{15}$ Lewis, Fascism and the Working Class in Austria, 7.

${ }^{16}$ Ibid., 69-70.

${ }^{17}$ Ibid., 69-70.

${ }^{18}$ Lynne Lawner, "Introduction," in Letters From Prison by Antonio Gramsci (New York: Harper and Row, 1973), 16-17.
} 
emphasized class conflict and prioritized cultural preparation over political initiative, ${ }^{19}$ fundamentally breaking with classical Marxism. This 'inheritor' theory defined the role of human beings as passive rather than active agents of revolution. Helmut Gruber draws a parallel between this vision of Marxism and popular interpretations of Gramscian theory, in which a counter-hegemonic culture is created by the workers prior to the seizure of state power. ${ }^{20}$

Both Blum and Gruber understand the SDAP perception of the working class as the inert subject of their radical reforms in a way similar to Donald's conception of the citizen as "empty space." Blum cites the party's manifesto tabled in Hainfeld in 1889, which outlined its role in 'filling' the proletariat, as one might fill a vessel, with class consciousness and physical and mental preparedness. ${ }^{21}$ Gruber similarly suggests hegemonic overtones in the SDAP's perception of proletarian consciousness as something malleable, to be transformed from its existing brutish state to one of enlightenment. ${ }^{22}$ Other critics have claimed that the Socialists inherited the Austro-Hungarian tradition of using institutions to stifle dissent and deliver a circumscribed political program. Josef Weidenholzer states that the SDAP "more or less unconsciously" adopted remnants of the feudal and ecclesiastical apparatus, in particular, that of the Roman Catholic Church, because the party was aware that non-institutionalized social movements had historically not survived in the Empire. ${ }^{23}$ In this view, the church was a model for socialist domination, providing a blueprint for securing longterm control over society. Further, Gruber asserts that neither the Christian Socials nor the SDAP debated the desirability of institutional intervention in family life, ${ }^{24}$ implying that their respective approaches had more in common than the Socialists were willing to admit.

Geoff Eley claims the rigid, top-down authoritarian structure of the SDAP led the party to disregard the "everyday" experience of the proletariat, preventing the Socialists from appreciating the "ambiguities and contradictions" complicating the lives of their supporters. ${ }^{25}$ Lewis

\footnotetext{
${ }^{19}$ Rabinbach, The Crisis of Austrian Socialism, 123-4.

${ }^{20}$ Gruber, Red Vienna, 184.

${ }^{21}$ Blum, The Austro-Marxists, 14.

${ }_{22}^{2}$ Gruber, Red Vienna, 34.

${ }^{23}$ Josef Weidenholzer, "Red Vienna: A New Atlantis?" in The Austrian Socialist Experiment: Social Democracy and Austromarxism, 1918-1934, ed. Anson Rabinbach (Boulder, CO: Westview Press, 1985), 196.

${ }^{24}$ Gruber, Red Vienna, 72.

${ }^{25}$ Eley, "Cultural Socialism," 335.
} 
similarly observes that although the party fostered a proliferation of socialist health, leisure, and educational clubs, it had little knowledge of enormously popular (though politically incorrect) proletarian institutions such as the Beisel, the Viennese pub-eatery, and did not attempt to replicate them. ${ }^{26}$ Gruber similarly claims that in certain major programs such as the housing projects, the working class had little input, leading to design flaws that unnecessarily increased their hardships. ${ }^{27}$

The most serious implication drawn by observers such as Weidenholzer is that the party's intellectual paternalism and ignorance of worker sub-culture somehow dulled the critical faculties of the proletariat. Ilona Duczynska, the Hungarian communist and founder of the first left-wing opposition bloc within the SDAP, accused Socialist institutions of fostering a "habitual fabric" responsible for suppressing the democratic impulse of the radical worker-soldier soviets that emerged during the unrest throughout $1918 .^{28}$

However, to conceptualize SDAP institutions as being fundamentally conservative, while admittedly transmitting some socialist values, is to miss the mutually constitutive relationship between the progressive and paternal qualities of the social welfare program as informed by AustroMarxism. The SDAP made a crucial distinction regarding the proletarian experience that Gruber and Eley do not address and which may best be seen in the educational reforms for middle and secondary schools introduced by Otto Glöckel. These reforms did accept the importance of inculcating critical thinking among working class students and can be seen as a possessing a hybrid 'passive-active' quality that may be interpreted as a synthesis of the ideas of civic identity respectively advanced by Habermas and Donald. The new "work schools" were to be the "incubators of democracy," abolishing corporal punishment and class hierarchies, encouraging experimentation and the questioning of traditional authority, and replacing rote memorization with self-discovery and independent learning; the city was to be as much the classroom as the traditional schoolroom. ${ }^{29}$ Most importantly, the curriculum was based on the life experiences of the students. ${ }^{30}$ True, these reforms had been implemented only on an experimental and limited basis by 1926, with only twelve schools completely adopting the new progressive curriculum in the face of widespread resistance from loyalist and conservative

\footnotetext{
${ }^{26}$ Lewis, Fascism and the Working Class in Austria, 82.

${ }^{27}$ Gruber, Red Vienna, 72.

${ }^{28}$ Duczynska, Workers in Arms, 27-31.

${ }^{29}$ Gruber, Red Vienna, 75, Rabinbach, The Crisis of Austrian Socialism, 28, 72.

${ }^{30}$ Gruber, Red Vienna, 75.
} 
teachers. ${ }^{31}$ The existence of these schools does, however, challenge Eley's view of the SDAP as a monolithic pedagogical entity largely disinterested in the proletariat worldview.

The 'passive-active' progressive-traditional program developed by the Socialists in response to the pressures of war, revolution, and counterrevolution can be observed in the efforts to expose the proletariat to Bildung and construct the Bildungsgemeinschaft. Rabinbach observes how the Socialists embraced the traditional liberal values of the Enlightenment: rationalism, humanism, universalism, cosmopolitanism, and parliamentary democracy, fused with a commitment to work towards proletarian interests. ${ }^{32}$ Seminal party figures such as Victor Adler believed one of the key mandates of the party was to use socialism as a conduit to deliver high German culture to workers. ${ }^{33}$ This 'cultural democratization' is heavily criticized by Gruber, who accuses party officials like Richard Wagner, David Joseph Bach, and Joseph Luitpold Stern of betraying SDAP cultural theory by adhering to the "narrowly defined Germanism" of their inherited liberal-humanist values. ${ }^{34}$ In this analysis, Stern and his colleagues are supposed to have effaced the socialist political message from their cultural programs, making only vague reference to class struggle. Gruber sees the resultant choice of cultural products promoted by the party as having an insufficiently revolutionary content, referring, for example, to a production of Faust staged for a working class audience as being "embarrassingly backward." ${ }^{35}$

It is true that this was a deficiency noted within the party at the time, with Wagner in particular lamenting the lack of a cultural theory paralleling the Socialists' political objectives. ${ }^{36}$ However, Gruber verges on elitism when he suggests the Viennese working class should have been exposed to explicitly revolutionary, and, by implication, nonbourgeois cultural products. The possibility that the Socialists may indeed have combined paternal and progressive themes in their cultural program does not occur to him. In so doing, Gruber suggests either that aspects of bourgeois culture would simply not have interested the working class, or, worse, that they subverted the proletarian consciousness and induced a 'psychic somnambulance' with dire

\footnotetext{
${ }^{31}$ Ibid., 77.

${ }^{32}$ Rabinbach, The Crisis of Austrian Socialism, 11.

${ }^{33}$ Blum, The Austro-Marxists, 10.

${ }^{34}$ Guber, Red Vienna, 85.

${ }^{35}$ lbid., 86.

${ }^{36}$ Ibid., 86.
} 
consequences for the revolution. The 'passive-active' dynamics in the SDAP's attempt to develop a social democratic people's republic are laid bare here. Whether or not constant exposure to Bach, Goethe, and Mozart distracted or damaged proletarian revolutionary ardour will be more fully examined later.

Eley's assertion that the socialists placed themselves in an "exterior relationship" to the so-called "everyday culture" of the working class, defined in terms of a mass consumer movement, assumes that such an autonomous sub-culture actually existed in the first place. ${ }^{37}$ However, elements of this "everyday culture," especially cinema, were in fact a product of bourgeois society. Further, if the classical liberal heritage was imposed on the proletariat, socialist interventionism at least exposed workers to important intellectual and artistic products they wouldn't otherwise have encountered. Although the Socialists' preoccupation with the 'proletarianization' of select aspects of bourgeois culture likely caused them to eschew popular cultural forms including film and radio that might have effectively disseminated social democratic values, as Gruber notes, ${ }^{38}$ the SDAP in effect 'democratized' a high German culture that had been the exclusive domain of the elite for centuries, a considerable achievement.

Socialist housing policy similarly appropriated bourgeois forms in a process of symbolic and material 'spatial democratization,' producing a patemal-progressive architectural pedagogy. Manfred Blümel records the architectural elements characteristically employed by Austrian social democracy, the "third way" between bolshevism and weak reformism. Symbolic democratization took place through the elimination of exterior decoration that both indicated a bourgeois residence and attempted to conceal the poverty within proletarian apartments, the trompe l'oeil that gave the false impression of Vienna as a city of palaces and noblemen. ${ }^{39}$ Frederic Morton similarly describes Vienna's elaborate pre-war efforts to maintain its image as a bourgeois fantasyland, noting the "...élan with which the city painted camival across squalor," the "...hand-kissing done in rags...wine songs sung by starvelings...heraldic fairy tales framing lives of grime. ${ }^{, 40}$ Yet while the socialist architects eliminated beletage,

${ }^{37}$ Eley, "Cultural Socialism," 335-6.

${ }^{38}$ Gruber, Red Vienna, 124.

${ }^{39}$ Manfred Blümel, "Socialist Culture and Architecture in Twentieth-Century Vienna," in Working papers in Austrian Studies 94-3 (Minneapolis: University of Minnesota, 1994), 6.

${ }^{40}$ Frederic Morton, Thunder at Twilight: Vienna 1913/1914 (New York: Charles Scribner's Sons, 1989), 197. 
the hierarchical sculptural facade on buildings indicating differences in wealth, they also employed the classic spatial layout of the pan-European aristocratic palace, the cours d'honneur, the monolithic central block and flanking structures enclosing a square on three sides with only one entrance. As Blümel notes, this arrangement was a metaphor for the proletarian 'seat of state' and workers' power, with additional practical applications as a defensive fortress. ${ }^{41}$

In addition to 'symbolic democracy,' there were patemalistic and topdown power asymmetries at play within the housing blocks, in which workers were clearly considered 'empty vessels' to be filled with the new socialist consciousness. Rabinbach observes how socialist architecture in the larger developments was designed to actualize communitarian values, ${ }^{42}$ altering the consciousness of those living within them through the shared use of support facilities including groceries, laundries, clinics, and leisure areas. Such housing was designed to provide a continuity of political life, channeling social behaviour towards collective and away from individual and bourgeois pursuits. ${ }^{43}$ Paternalism was also evident in the strict rules governing the use of such facilities that tenant committees were unable to effectively contest, including periodic invasive health inspections of apartments. ${ }^{44}$

At the same time, however, the 'spatial democratization' of living space undoubtedly improved workers' lives. The most obvious achievement was the sheer number of new apartments, 58, 667, built between 1924 and $1934 .^{45}$ Living space increased and housing density declined from eighty-five per cent of a given site in the late nineteenth century to thirty per cent during the inter-war years. ${ }^{46}$

Otto Bauer, chair of the SDAP's national parliamentary delegation and uncontested head of the party throughout the First Republic, embodied the party's contradictory understanding of the role of the citizen in a social democracy. This appears the result of a combination of his mechanistic understanding of Marxism as an inevitable historical process by which the Socialists would inherit power, thus reducing the need for proletarian activism outside the realm of purely parliamentary democracy, Austria's vulnerable economic and political situation in the post-war era, and what Rabinbach records as Bauer's own passionate

\footnotetext{
"Blumel, "Socialist Culture and Architecture," 9.

${ }^{42}$ Rabinbach, The Crisis of Austrian Socialism, 28.

${ }^{43}$ Blümel, "Socialist Culture and Archilecture," 8.

${ }^{4}$ Gruber, Red Vienna, 69.

${ }^{45}$ Bbid., 46.
}

${ }^{46}$ Blümel, "Socialist Culture and Archilecture," 4-5. 
belief in democracy. ${ }^{47}$ Bauer's writings suggest he believed the Austrian Republic had come about as a result of the larger contradictions of capital, forces beyond the control of the party. He saw the Austrian Revolution as the by-product of historical forces that had smashed apart the Empire, namely, the Great War and the subsequent actions of the Czech, Yugoslav, and Polish bourgeoisie. It was not, as such, a purely indigenous revolution of Austrian workers; rather, the proletariat had taken advantage of these outside occurrences to destroy the Habsburgs, ${ }^{48}$ a view echoed by the contemporary English observer C.A. Macartney. ${ }^{49}$

While Bauer could write of, on the one hand, the mechanistic progress of history from capitalism to socialism, in which the Republic had been brought into being as a consequence of titanic forces rending central Europe, he also spoke of how social democracy had spared Austria the horrors of counter-revolutionary violence. Bloody civil war had erupted when worker-soldier soviets had taken control in Bavaria and Hungary in fall 1918, unlike in Austria, where moderate socialism had appeared responsible for preventing a similar carnage. ${ }^{50}$ The implication is that ungovemed proletarian activism would inevitably provoke a counter-revolution, leading to disaster. In Bauer's view, the truncated post-war Austrian state, shut out of the markets of the nations of the former Empire by a tariff barrier, subjected to an austerity program by the League of Nations in exchange for a massive federal loan to stave off bankruptcy in 1922, and closely monitored by Allied officials to ensure compliance with the 'structural adjustments, ${ }^{, 51}$ was too weak to risk revolutionary violence. Popular passion had to be controlled in this sensitive period, particularly by 1925 , when revolutionary conditions had long since ceased to exist.

Yet what Rabinbach terms Bauer's "long view," the idea of the evolution of socialism, held out the promise of a future democracy negotiated by the younger generation, some of whom were then being trained in the experiential educational curriculum. ${ }^{52}$ Bauer could

\footnotetext{
${ }^{47}$ Rabinbach, The Crisis of Austrian Socialism, 121.

${ }^{48}$ Otto Bauer, The Austrian Revolution, trans. H.J. Stenning (London: Leonard Parsons, 1925), 283.

${ }^{49}$ C.A. Macartney, Social Revolution in Austria (Cambridge: Cambridge University Press, 1926), viii.

${ }^{30}$ Bauer, The Austrian Revolution, 187.

${ }^{51}$ F.L. Carsten, The First Austrian Republic, 1918-1938: A Study Based on British and Austria Documents (Brookfield, VT: Gower Publishing Company, 1986), 49-50.
}

${ }^{32}$ Bauer, The Austrian Revolution, 175. 
conceive of grass-roots democracy as the idealistic essence of social democracy that would flourish at some point in the future, when the inexorable forces of history, like rusty cogs controlling long-closed dam gates, ground into motion and brought forth global socialism as in a flood. But conditions in the short term were too desperate to allow independent worker councils to exist. Aware both of their popularity and the precarious position of the Republic, Bauer extolled the efficacy of these soviets operating within the SDAP's reformist framework, claiming in 1925 that they still exercised a "powerful influence" in Austrian politics, unlike the since-liquidated councils in Germany and Hungary. ${ }^{33}$ However, as Duczynska notes, the Austrian soviets had already been brought completely under the control of the Socialist Party by November 1924 and possessed no independent power. ${ }^{54}$ In a later passage, Bauer had a quite different view of the desirability of popular democracy in the near future: "We could only rule the masses with intellectual means." 55

Bauer's distrust of popular democracy was shaped by Austro-Marxist theory as it evolved in the fractious years of the First Republic. As the Christian Social-dominated coalition tightened its grip on the federal government and the SDAP narrowed its focus to cultivating an electorate in the city and province of Vienna, Bauer developed the theory of the "balance of class forces." Conditioned by Austria's unusually configured polity, Bauer believed that a power equilibrium, as opposed to a conflict, existed between the competing groups. Deviating from the classic Marxist conception of class conflict, Bauer perceived the state not as a collection of institutions to be seized in violent political struggle, but as a neutral democratic entity, a "pure form" that would slowly and peacefully pass into the hands of the proletariat as it was filled with SDAP social-cultural content. ${ }^{56}$ Stability was the key to this gradualist approach. The institutional apparatus preparing the proletariat for mass participation in federal elections could not in any way be jeopardized by the destructive force of "premature" popular politics. ${ }^{57}$ As such, the SDAP was ambivalent towards the working class: depending on its actions, it could either win the revolution or deliver it into the hands of its enemies. Consequently, Bauer's principle of 'progressive paternalism,' the distillation of what was perceived as the best of the

\footnotetext{
${ }^{53}$ Ibid., 187.

54 Duczynska, Workers in Arms, 59.

${ }^{35}$ Bauer, The Austrian Revolution, 178.

${ }^{56}$ Bbid., 40-1.
}

${ }^{57}$ Rabinbach, The Crisis of Austrian Socialism, 120. 
socialist and bourgeois worlds, informed by the theory of the balance of class forces, envisaged a central but carefully moderated role for the proletariat. The firm hand of the party would guide workers through their 'adolescence,' steep them in the responsible and disciplined use of power, and bring them into 'maturity.'

However, the Christian Socials and their allies, unlike the Socialists, were increasingly prepared to use deadly force to maintain state control and dismantle the SDAP social welfare program as the 1920s progressed. One of the central questions critics have focused on in assessing the legacy of the Socialist municipal institutions was whether party paternalism was responsible for de-politicizing or de-radicalizing the proletariat as street confrontations with right-wing police and paramilitary groups increased. Weidenholzer claims that the 15 July 1927 police assault on demonstrators resulting in eighty-five deaths was proof positive that this was indeed what had occurred. The discipline imposed by "church-like" party institutions is supposed to have had a soporific effect on the political consciousness of the proletariat in this episode. As a result, "...the rank and file were not capable of reacting autonomously without their leaders' commands."

Yet precisely the opposite had taken place. The massive protests were spontaneous, not organized by the Socialist Party, and workers and members of the Schutzbund self-defence militia had begged party functionaries to open the armouries in order to defend themselves. Bauer in fact hid himself from a delegation of city electrical workers who wanted to cut the power in protest. ${ }^{59}$ Gruber devotes several chapters of his book to criticizing the ineffectiveness of the SDAP cultural program, emphasizing that workers largely ignored the party's workshops and avalanche of difficult theoretical literature, much preferring to relax at the cinema or at football games after hours of hard labour. ${ }^{60}$ It is possible that Bauer's admonishments that workers actively devote additional after-work volunteer hours to participating in municipal and county government and the myriad committees established in virtually every sphere of urban life had a demoralizing effect, ${ }^{61}$ especially considering the widely-documented inability of these bodies to influence SDAP social policy in any substantive way.

However, Gruber's suggestion that the shortcomings of the cultural program had important effects on proletarian consciousness is less

\footnotetext{
${ }^{58}$ Weidenholzer, "Red Vienna: A New Atlantis?," 196.

${ }^{39}$ Gruber, Red Vienna, 41.

${ }^{60}$ Bbid., 87-91.

${ }^{61}$ Bauer, The Austrian Revolution, 174.
} 
tenable. Of his claim that there were three "insurmountable contradictions" within the party's cultural program that placed all the achievements of the Socialists at risk, only the last, the attempt to "...safeguard and work within the democratic institutions of the republican state and to combat the class state at the same time" can be considered as meeting this requirement. ${ }^{62}$ Gruber does not focus on this point, since his book is primarily a cultural and not a political history of Red Vienna, but rather on the flaws he perceives within the cultural program he believes were germane to the integrity of the Republic. The other two "contradictions," the appropriation of bourgeois culture while simultaneously creating a closed proletarian counterculture dedicated to class struggle and the commitment to promote collective over individual cultural development ${ }^{63}$ cannot be considered fundamental to the Republic's survival. In fact, the spontaneous protests of summer 1927 and the almost complete breakdown of the party leadership in the subsequent events prove that workers had not been neutralized by an insufficiently revolutionary cultural program. They did not on that or other occasions call for copies of Beethoven's Fifth Symphony or Heinrich Mann's Professor Unrat, but for arms.

In a similar vein, Eley states that the party's neglect of popular and especially entertainment culture, which was important because it occupied "...so thickly the human space of the everyday," somehow prevented the party from transmitting their political message to young working class people, especially women. ${ }^{64}$ The fascists, on the other hand, embraced popular "...needs and longings the Left neglected to its peril." $" 65$ The implication here is that the insistence of the Socialists in pushing their puritanical, drab dogma on a recalcitrant proletariat drove away potential recruits and strengthened reactionary forces. Though it is true the Socialists never developed a strong apparatus in the provinces, ${ }^{66}$

\footnotetext{
${ }^{62}$ Gruber, Red Vienna, 82.

${ }^{63}$ Ibid., 82.

${ }^{64}$ Eley, "Cultural Socialism," 336.

${ }^{65}$ Ibid., 336.
}

${ }^{66}$ Lewis, Fascism and the Working Class. Lewis claims that the relative weakness of Socialist institutions in the provinces, especially Styria, created a power vacuum that allowed the right wing to co-opt alienated workers and develop a power base from which the successful counter-revolution of 1934 was launched. This is an attractive theory in assessing the reasons why the First Republic fell. As such, the SDAP's cultural program was likely not a major factor in these developments. The unique post-war socio-political environment impelling the party to concentrate its resources in the city and province of 
the party had wide popular support in Vienna throughout the First Republic. It expanded its membership in this city of almost two million from 123,684 to 418,055 between 1920 and $1929,{ }^{67}$ suggesting that the SDAP's neglect of popular entertainment and media and the relative unpopularity of their cultural program had little to do with the motives of the proletariat in joining the socialist movement.

Eley's implication that young workers were frivolous and obsessed with sensate pleasures is undermined when it is considered that the roots of the left opposition to the SDAP's conciliatory tactics in Vienna after the 1927 massacre came from the party's youth wing, the Socialist Worker Youth (SAJ). Here is evidence of a strong political entity that existed despite the Socialists' cultural program and monopolization of politics, as well as the supposedly strong pull of "everyday" popular proletarian culture. Rabinbach observes that the SDAP's left wing had always been associated with the party's youth organization, which formed the nucleus of its anti-war movement in the First World War. Most important was the party's contradictory dual ethos, which bred an acceptance of paternalism and willingness to obey authority and at the same time encouraged youth to question and view as illegitimate this same authority, especially in the organizations dedicated to training older youths. ${ }^{68}$ Rabinbach records the growing militancy of the SAJ by 1930 and its increasing affiliation with the Austrian Communist Party's revolutionary program in the face of the deteriorating economy and the SDAP's indecisiveness as right-wing street terror mounted. A fierce struggle ensued in which the Socialists attempted to prevent both the SAJ and the radical splinter movement known as the Jungfront from pursuing independent political activism. Far from being cowed by the SDAP institutional-cultural program, young workers had in fact been trained by it to challenge party directives; they were then radicalized by the party's inertia in a period of escalating crisis, forming a core of opposition among renegade socialists including Emst Fischer, Karl Mark, and Franz Schuster. ${ }^{69}$

As such, the history of Red Vienna can be conceived as a protracted struggle between Socialist Party workers and intellectuals to realize their respective forms of democracy. Economic, political, and pedagogical considerations shaped the conviction of party leaders that popular

Vienna to the exclusion of the hinterland seems a much more plausible factor undermining Socialist power.

${ }^{67}$ Ibid, 81.

${ }^{68}$ Rabinbach, The Crisis of Austrian Socialism, 72.

${ }^{69}$ Ibid., 84. 
democracy might endanger the revolution by creating soviet-style bodies that would invite counter-revolution, or even Allied intervention. The memory of the expeditionary force sent to aid White Russia in 1918 was no doubt fresh in their minds. Party intellectuals understood 'responsible' democracy as being incubated under the conditions outlined by AustroMarxist theory, through the gradual cultivation of the proletarian social democratic consciousness directly via schools and indirectly through the social engineering of the housing estates, out of which a fully-formed socialist utopia was expected to someday blossom. The soldiers and workers themselves saw things differently. To them, the problems of unemployment, hunger, and right-wing terror were pressing, demanding summary democratic initiative. They immediately elected their own leaders to take action as the situation warranted, be it the spontaneous occupation of the Vienna arsenal in January 1918, preventing the huge store of arms from falling into government hands, ${ }^{70}$ or the spontaneous call to arms in Vienna and Linz in February 1934 to resist the impending coup of the Dollfus regime as the SDAP leadership broke apart and dissolved.

It cannot be said either that the party viewed citizens purely as "empty space" to be defined by whatever the "Law" dictated, on the model Donald proposes. Though the great Austrian social democratic intellectuals including Otto Glöckel, Victor Adler, Max Adler, Karl Renner, and Otto Bauer saw workers as needing the guiding hand of the party and constant tutelage in preparation for the revolution, regarding Austro-Marxism's esoteric Kantian synthesis as warranting long hours of hard study, there is evidence they saw value in grass-roots activism in a more stable period far in the future when the party had 'inherited power.' For all its faults, the SDAP's socio-cultural program did sow the seeds of popular democracy, imbedding processes of critical thinking within pedagogical programs and institutions. The youth organizations and later the Schutzbund militia did breed precisely the sort of independent opposition the party had fought so hard to suppress between 1918 and 1924. Armed resistance in 1934 did centre on the great housing 'fortresses,' which fulfilled their role as proletarian redoubts as planned, though in a losing cause.

The party's high-handed delivery of cultural programs did not dilute proletarian revolutionary consciousness, as some critics have charged. In 1918,1927 , and 1934, the workers themselves consciously or unconsciously acted according to the fundamental principle of revolution as dictated by classical Marxism: that the motive force of historical

${ }^{70}$ Duczynska, Workers in Arms, 27-31, 55. 
materialism, the movement of history from one stage to the next, is class conflict, resulting in the seizure of the state and the means of production by the victor, the very dynamics eschewed by the Austro-Marxists. As the setting for the relationship between the SDAP and the proletariat and the struggle to liquidate and reconstruct popular democracy, to reconcile the contradictions produced by the clash between progressive and traditional values, between paternalism and popular politics, Red Vienna embodied the characteristic dynamics of "modernity" as Marshall Berman understands them, the fusion of "unending permanent revolution...[and]...the violent overthrow of all our values" with the "romance of construction."

${ }^{71}$ Berman, All That Is Solid Melts Into Air, 30. 